University of Nebraska - Lincoln

DigitalCommons@University of Nebraska - Lincoln

Faculty Publications - Department of

Philosophy

Philosophy, Department of

7-1994

Maxims in Kant's Moral Philosophy

Nelson T. Potter Jr.

University of Nebraska - Lincoln, kjohnson6@unl.edu

Follow this and additional works at: https://digitalcommons.unl.edu/philosfacpub

Part of the Continental Philosophy Commons, and the Ethics and Political Philosophy Commons

Potter, Nelson T. Jr., "Maxims in Kant's Moral Philosophy" (1994). Faculty Publications - Department of Philosophy. 13.

https://digitalcommons.unl.edu/philosfacpub/13

This Article is brought to you for free and open access by the Philosophy, Department of at DigitalCommons@University of Nebraska - Lincoln. It has been accepted for inclusion in Faculty Publications Department of Philosophy by an authorized administrator of DigitalCommons@University of Nebraska - Lincoln. 


\title{
MAXIMS IN KANT'S MORAL PHILOSOPHY
}

\author{
NELSON POTTER
}

It has been noticed in the English-language literature concerning Kant's ethics, at least since Marcus Singer's extended discussion in later chapters of Generalization in Ethics ${ }^{1}$ that the concept of a maxim plays a central role in the application of the categorical imperative, and that it is, for that reason, if not for others, worth detailed attention. In the present essay I wish to consider the Kantian concept of maxim in a broader context.

The present paper builds its interpretation of maxims upon what Henry Allison calls Kant's "Incorporation Thesis", a thesis which asserts that the adoptions of maxims are the primary acts of freedom, and that any aspect of ourselves for which we are responsible is something which has been "taken up" and "incorporated" into our maxim. ${ }^{2}$ I will show that Kant thinks that there are three different kinds of things that are in this way objects of choice, and hence are "taken up" and incorporated into our maxims: our basic moral character, our basic ends of action, and our actions themselves. Further, in the model that Kant sometimes presents of the morally perfect finite being, the being who unqualifiedly exhibits good will, there are important connections among these distinct elements of maxims, especially in the case of morally good action, where the moral goodness of one's character determines the end of action and the end determines the action. This connection of elements within Kantian maxims makes explicit the main connections between Kant's theory of moral goodness and his theory of the moral rightness of actions. The latter theory is illustrated by the much discussed four examples of the application of the categorical imperative in Chapter Two of the Grundlegung, and by the second half of Kant's late work, the 
Metaphysics of Morals. But because these parts of Kant's theory have often been discussed in isolation, the significant connections between moral goodness and right and wrong in Kant have often been overlooked. One of the best ways of bringing out such connections is through a detailed and full examination of what Kant has to say about moral maxims.

In part I of this paper I briefly review the recent history of the interpretation of Kantian maxims, and present the main Kantian texts on which it has been based. In Part II I consider John Atwell's threefold account of maxims. In part III I give an extended account of Allison's discussion of maxims in his recent book Kant's Theory of Freedom. It is one of the fullest accounts of the nature of maxims that we have, and brings up some of the issues I wish to deal with in my positive interpretation. Thus the discussion of Allison will provide us with some of the main topics for this essay. In Part IV I present my own account of maxims. Part $\mathrm{V}$ presents one of the implications of the interpretation of maxims I have presented, viz., that Kantian maxims are quite different from rule utilitarian rules.

I

Marcus Singer was interested in finding criteria for arriving at unique correct descriptions of actions for the purposes of moral evaluation, and this was one of the reasons why he concentrated his attention on Kant's account of maxims in his discussion of Kant in the later chapters of Generalization in Ethics. ${ }^{3}$ Other writers had the same interest, notably Jonathan Harrison in his essay "Kant's Examples of the First Formulation of the Categorical Imperative." ${ }^{4}$ Harrison had also made a major contribution to the discussion of criteria for action description in a context of rule utilitarianism. ${ }^{5}$ And in the 1970 s another major work on Kantian ethics, Acting on Principle by Onora (O'Neill) Nell, ${ }^{6}$ paid considerable attention to the formulation of maxims. An essay of mine published in 1975 also aimed to make a contribution to this same sort of issue, by proposing causal criteria for action descriptions, that were adapted from David Lyons' Forms and Limits of Utilitarianism, ${ }^{7}$ where causal criteria for action descriptions within proposed moral rules in a utilitarian context were proposed. I will discuss my own essay a bit further below, and attempt to add to 


\section{MAXIMS IN KANT'S MORAL PHILOSOPHY}

what it had to say. All these discussions of the Kantian concept of maxims consider them primarily in relation to applications of the categorical imperative in deriving specific conclusions about the rightness and wrongness of particular kinds of actions. This was the major focus of the discussion of Kantian moral maxims through these years.

These discussions almost all note the repeated Grundlegung definition of maxim as a subjective principle of volition or action (G, IV, 400n, 420n; compare KdpV, V, 18-19; MdS, VI, 225), in contrast with imperatives, which are said to be objective. Such discussions also take note of the examples of actual maxims that Kant gives in the well-known four examples of Chapter Two of the Grundlegung and elsewhere. Most of these examples arise from applications of the categorical imperative to derive a specific duty. Some of these authors note that the fact that the categorical imperative is applied to maxims is extremely helpful in determining how the action is to be described for the purposes of moral evaluation. (Egs., Singer and Nell)

Kant's actual examples of maxims mostly simply mention a general kind of action, which is to be performed in particular circumstances, perhaps to accomplish a certain end. Thus Kant speaks of "the maxim of getting out of a difficulty by a false promise." (G, IV, 402; compare a fuller version of the same maxim, G, IV, 422, and another example of a perfect duty to another at $\mathrm{KdpV}, \mathrm{V}, 27)$ The maxim of suicide is given as follows: "From self-love I make it my principle to shorten my life if its continuance threatens more evil than it promises pleasure." (G, IV, 422) Both of these examples call for the performance of a certain kind of action and the second additionally suggests that the action is to be done for the sake of a certain end, or out of a certain kind of motive. The phrase "from self-love" in the suicide maxim may be taken as a generalized reference to the end of being happy or avoiding pain, or the motive of self-love. But most of Kant's actual examples of maxims do not include any explicit mention of the end of action.

Again, Kant's definitions of "maxim" are as "the subjective principle of a volition" (G, $400 \mathrm{n}$ ) or "a subjective principle of action" ( $G, 420$ n Cf. KdpV, V, 18-19; where maxims are characterized as subjective practical principles.) The word "subjective" means that a 


\section{NELSON POTTER}

decision or choice of the agent has resulted in the adoption or acceptance of the maxim by the agent. Maxims merely considered for adoption or entertained or under discussion are merely potential maxims. The word "subjective" also means that the maxim holds or is "valid" only for the agent ( $\mathrm{KdpV}, 19$, cf. G, 420n), in contrast to objective principles or imperatives, which are regarded as binding on all agents.

In sum, maxims are policies of action adopted by agents, and are the primary objects of moral assessment in applying the categorical imperative to determine the rightness or wrongness of actions. These assessments of the moral quality of maxims are sensitive to the action description that is the central element of the maxim, and so some attention needs to be given to how this description is to be formulated or arrived at. Furthermore, though this was more assumed than asserted, maxims are single element principles that, as verbally formulated, indicate a kind of action to be performed in certain kinds of circumstances, together with the agent's commitment to a general policy of performing such actions when appropriate circumstances arise. Thus, it seems natural to say that in adopting a maxim the agent is basically setting a rule for herself to follow. So on this "standard account" of the nature and function of moral maxims, as I shall call it, maxims (i) formulate a rule of action, and (ii) express the agent's resolve to act by that rule.

Now let me indicate some other Kantian texts that point towards certain additional aspects and roles for maxims. (1) Kant tells us that maxims include not just a mention of a kind of action, but also the end for the sake of which such an action would be performed. He comes close to saying this in the Critique of Practical Reason, where he is talking about maxims as one kind of practical principle, and says, "The material of a practical principle is the object of the will." (KdpV, V, 27) Then in the Doctrine of Virtue (second part of the Metaphysics of Morals) he speaks of the matter (Materie) of maxims, which is "an end which is at the same time conceived as a duty." (MdS, VI, 394-5), and soon tells us that the supreme principle of the doctrine of virtue is "Act according to a maxim whose ends are such that there can be a universal law that everyone have these ends." (MdS, Vl, 395) 
(2) In Chapter One of the Grundlegung, when Kant is giving an exposition of the concept of action from duty, he speaks of the maxims of actions from duty, and only of such actions (that is, only of such actions as exhibit the characteristic moral goodness) as having "moral content (sittliche Gehalt)" (twice at G, IV, 398). This usage makes it clear that the "content" of a maxim will tell us, not just whether the action it proposes is right or wrong, but also whether it is morally good or not; that is, the content of the maxim also tells us about the motives on which the action is based. This quite clear statement is not further developed in the Grundlegung.

(3) In Book One of Religion Within the Limits of Reason Alone, Kant sets forth his conception of original sin. Such sin is conceived as a wrongful action which is the personal responsibility of the agent. Those things which we are responsible for are all and only those elements that we choose by incorporating them into our maxim. Kant writes, "...an incentive can determine the will (Willkuer) to an action only so far as the individual has incorporated it into his maxim..." (R, VI, 24; 19) (This is what Henry Allison calls "the Incorporation Thesis," as mentioned above and discussed further below.) Kant then develops the concept of the "supreme maxim" (R, VI, 31;26), which is a purely formal maxim that the agent adopts by a timeless noumenal act, "an intelligible action, cognizable by means of pure reason alone, apart from every temporal condition..." (R, VI, 31; 27) The maxim is purely formal in the sense that it relates merely to the subordination of personal incentives to moral incentives in the agents' maxims. (R, VI, $36 ; 31)$ The morally good person puis the incentives in proper order, giving morality priority over personal desires. The morally evil person reverses the order, by being willing to follow moral imperatives only so long as they do not conflict with the pursuit of personal desires. Here the supreme maxim defines the agent's entire moral character as good or evil, whereas in the Grundlegung the maxim defined the moral goodness or its lack, only for an action.

These three aspects of maxims, as including (1) ends, and the moral goodness of (2) actions and (3) character, are omitted from the "standard account" of Kantian moral maxims. 
NELSON POTTER

II

A recent interpretation of maxims recognizes some of the complexity that is suggested by the three groups of texts just noted, John E. Atwell's Ends and Principles in Kant's Moral Thought. ${ }^{8}$ Chapter Three is devoted entirely to a discussion of maxims. Atwell there urges that there are three kinds of maxims, which he calls

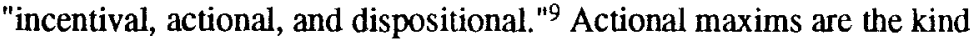
we are most familiar with from Kant's actual examples of maxims. These kinds of maxims are the focus of the "standard account." Incentival maxims are ones which determine the moral goodness of particular actions, and are held to be distinct from actional maxims. The textual basis for such maxims comprises the statements from Chapter One of the Grundlegung that the moral worth of maxims is determined by the "moral content" of the maxim of the action $(\mathrm{G}, \mathrm{V}$, 398), discussed above. These sorts of maxims determine not the moral rightness of a given action type, but rather the moral goodness of certain particular actions. Finally, the distinction of dispositional maxims as a third kind of maxim is based on Book One of the Religion, discussed above. This third sort of maxim has a clear textual basis from the Religion, and it is also clearly distinct from both of the other kinds of maxims, which determine the moral rightness of actions, and, according to Atwell, the moral goodness of specific actions.

Atwell's discussion has some clear and definite merits, and in several ways represents an advance on all earlier discussions of the same topics. Its basic merit is that it recognizes distinct functions of maxims that are not taken account of by the "standard account." Each of the functions of maxims is well-founded in the Kantian text, and each deserves comment.

1. Atwell does not relate Kant's theory of maxims to his theory of freedom. This is something that could be usefully done, both by way of providing unity to Kant's views of maxims greater than that provided by Atwell's interpretation, and by way of further explaining why Kant has the views he does. Atwell lays the ground for making this interpretive move in Chapter II of his book, on the good will (a discussion of the opening paragraphs of Chapter One of the Grundlegung), which emphasizes that the value of good will is one we 


\section{MAXIMS IN KANT'S MORAL PHILOSOPHY}

make for ourselves, by our own actions. In this way Atwell relates the doctrine of the unconditional goodness of the good will to freedom and our use of it. However, Atwell does not carry this theme to his discussion of maxims in his next chapter.

2. Atwell does not relate the three kinds of maxims to one another. This leaves Kant's moral theory in three parts, without making it clear how those parts relate to each other. We might even ask why, according to Atwell's interpretation, should Kant have called three such different sorts of things by the same name, "maxims"? I will later argue for connections among these different maxims or aspects of maxims.

3. As Atwell proposes three different kinds of maxims, I propose below three different aspects of maxims. But his three are different from my three. His three are actional maxims, incentival maxims, and dispositional maxims. In contrast the three aspects of maxims that I distinguish below are those that are related to (1) kinds of actions, (2) ends of action, and (3) incentives for action, as an expression of moral character. In addition to adding the adoption of the ends of action to the functions of maxims, I see Atwell's incentival and dispositional maxims as involving a single function relating to moral goodness, whether of actions or of the person. My own view is that incentives relate only to character (as revealed in some actions), and that Kant neither has nor should have a separate account of the moral value of actions as distinct from the moral goodness of persons. ${ }^{10}$

III

Henry Allison's Kant's Theory of Freedom presents an extended discussion of maxims (KToF, pp. 85-94), which both discusses much of the earlier literature, and goes beyond it to make significant new contributions. Allison begins, as we did above, by considering Kant's definitions of maxims, their contrast with imperatives, and his examples. Summing up this first part of his discussion he writes, "In light of these considerations, a maxim may be characterized as a selfimposed, practical principle or rule of action of the form: When in Stype situations, perform A-type acts," (KToF, pp. 89-90) a characterization based both on Kant's examples of maxims and his definition of the term. Thus far Allison's discussion corresponds to the 
"standard account." Allison also refers to the "deep structure" of maxims, which "need not be, and, in fact, usually is not made explicit." (KToF, 90) He quotes the suicide maxim mentioned above, with its opening phrase "From self love...," to illustrate this deep structure of motivation for adopting a maxim. He regards this element as present in all maxims, even when it is not explicit.

Allison then discusses an alternative interpretation, presented in different forms by Otfried Hoeffe, Ruediger Bittner, and Onora O'Neill (KToF,91ff.). ${ }^{11}$ These three insist that "only the most general selfimposed rules or practical principles under which an agent acts are to be regarded as maxims." (KToF, 91) More specific (and rigid) rules might be called, and are called by Allision Vorsaetze, and are regarded as subordinate to maxims proper. This way of looking at maxims is proposed in the hope of avoiding the complications and implausibilities resulting from consideration of quite specific rules as candidates for universalization. The unlikely idea that the categorical imperative might somehow be able to churn out such specificities as "Always offer your morning guests coffee with sugar and cream" is precluded by this strategy of keeping maxims at a much more general level, one at which they may appropriately be called Lebensregeln. Avoiding the multiple implausibilities of the conception of Kant's ethical theory linked with Vorsaetze is no doubt also what lies behind O'Neill's repeated statement (in Constructions of Reason) that the categorical imperative does not provide an "algorithm" for deriving moral duties. ${ }^{12}$

While acknowledging the usefulness of this approach, Allison does not fully accept it. He points out that many of Kant's actual examples of maxims (including those quoted above) seem to contradict this view, and, responding to one of O'Neill's arguments for her view, he also points out that "Kant's agnosticism regarding the real morality of our actions need not be taken as an agnosticism about our maxims." (KToF, 93) Allison's own conclusion is that "Kantian maxims come in various degrees of generality....one might think of maxims, in analogy with conceptions (considered intentionally) as arranged hierarchically, with the more general embedded in the more specific, like genera in species." (KToF, 93) In addition, he brackets for later 
discussion, the doctrine of the Religion that the "ultimate subjective ground" of the adoption of maxims is itself a maxim..$^{13}$

The assumption of this "standard account" is that maxims have the character of a single, simple formula which mentions a kind of action at some level of abstractness and remoteness from the immediate situation--O'Neill and company insisting that the description should constitute a Lebensregel more removed from the specificities of action and thereby closer to the agent's underlying moral character, and others thinking differently. Allison finally proposes a nested hierarchy of action descriptions, though he also admits that such a conception seems incompatible with the assumption of a single correct formulation that seems necessary for the moral test of applying the categorical imperative to the maxim. (KToF, 93-4; Kant seems to suggest different levels of maxims at MdS, VI, 411.)

The weakness of all of these accounts is that they do not recognize what I will call the internal complexity of maxims. (Allison comes closest when he talks about the "deep structure" of maxims.) Arguably, what Bittner, Hoeffe, O'Neill and Allison are groping toward is a recognition in one's account of maxims of what I will insist upon below, that there is more to maxims than the quite specific action descriptions of the standard account. I speculate that they are hampered in presenting their views by the (unstated) assumption that maxims are straightforward unidimensional statements that consist of some sort of broad description of a policy of action, and nothing more. They propose an account of maxims as Lebensregeln to try to take account of those elements of maxims mentioned in the Kantian texts that do not relate closely to specific actions. The Kantian lack of moral self knowledge that $\mathrm{O}^{\prime} \mathrm{Neill}$ mentions and Allison comments upon (KToF, 93) may have to do with an element of the maxim, that element having to do with motivation, without also carrying over to the actiondescription portion of the maxim in such as way as to suggest that that part of the maxim is abstract, far removed from specific actions, and at least partially obscured from our own view.

Meanwhile, Allison, after seeming to subscribe to this "standard account" in his preliminary discussion (from pp. 89-90), finally recognizes the need for greater complexity with a distinction and a summing up statement: 
This difficulty [viz., that the role of maxims in practical reasoning and the application of the categorical imperative requires a single correct formulation of the maxim] can be met, however, if we distinguish between the maxim on which an agent actually acts and other, more general principles, likewise maxims, that are implicit in the operative maxim as "background conditions" without being explicit factors in the decision. On this view, the relatively specific maxims on which agents usually act, for example, the maxim of false promising, presuppose more general principles in the sense that a commitment to the maxim entails a commitment to the more general principle (though not vice versa). (KToF, p. 94; compare a similar distinction made in replying to O'Neill on p. 93.)

Allison then adds that the doctrine of the "supreme maxim" from the Religion requires that we recognize that maxims work to specify not only specific right or wrong actions but also the goodness or badness of the underlying disposition. (KToF, 94) But though Allison returns in Chapter Seven to discuss this doctrine from the Religion (KToF, pp. 136-145, which is on Kant's concept of Gesinnung), this discussion does not do much to integrate the Gesinnung-maxim, as we might call it, with the earlier discussion of maxims.

There are two other aspects of Allison's discussion of maxims that are quite useful for any interpreter of maxims. One, having to do with whether the relations of the parts of the maxim to each other are causal or logical, will be discussed at the end of Part IV. The second was mentioned at the beginning of this paper: the fact that Allison names and assigns considerable importance to what he calls "the Incorporation Thesis" (KToF, 40), which he describes as underlying "virtually everything Kant has to say about rational agency." (40) Desires or anything else which relate to our actions become reasons for action only by being taken up into the agent's maxim and being incorporated into it. Finally the significance of this doctrine is that maxims are the focus of Kant's theory of freedom. The primary acts of any sort, which 
are imputable, for which we are responsible, are the adoptions of maxims; and conversely any aspect of our personal responsibility must be considered to be a part or an aspect of our maxim. This finally makes it clear, as I'll show below, that since we, in Kant's view, choose to adopt our moral character, our ends of action, and our policies of action, all three must be included in some way in the maxim. Kant's doctrine of maxims and his doctrine of free choice are thus very closely related and must be considered together.

Allison's whole discussion, then, though it considerably advances matters, leaves two issues unresolved. (1) We need a unique statement of the maxim for the purposes of moral assessment relative to the categorical imperative, and yet Allison and, as he notes, several others have suggested multiple formulations of maxims at different levels of abstraction. Which then is correct? Is there one unique correct formulation of a given maxim, or are there several different equally correct formulations? (2) Allison proposes a version of what I've called the "standard interpretation" on KToF, 89-90, and yet he seems to take it back in our last quote from $\mathrm{KToF}, 94$, where he admits different senses and perhaps kinds of maxims, a position that seems somewhat in conflict with his earlier formula. Allison seems led into these complexities and difficulties because he sees the variety of different functions Kant has for maxim: action-descriptions, used to determine the rightness of actions, and motive-descriptions relating to the moral goodness or evil of persons or actions, for two. Which view is correct, the "standard account" or the "multifunctional account"? I hope to answer these questions by giving a different interpretation of maxims, to which I now turn.

\section{IV}

My account of the nature of maxims is as follows. First, maxims are thought of by Kant as containing whatever elements we can be regarded as having chosen, and hence whatever elements we are responsible for. Second, he thinks that there are three such elements: our moral character as moral agents (our moral goodness or evil), the end or goal of our actions, and the kind of action itself.

The evidence that maxims contain descriptions of kinds of actions, as we've seen above, is considerable. This idea is supported by all of 
Kant's examples of maxims. The evidence that maxims include the choice of one's moral character is drawn from Book One of Religion Within the Limits of Reason Alone. (Eg., see R, VI, 24-25; 20-21) The singular maxim which describes and determines our moral character is a purely formal maxim which Kant calls the "supreme maxim." (R, VI, 31; 26) In the morally good person the supreme maxim aims to give priority to moral considerations over considerations of personal happiness; in the morally evil person the order is the reverse. (R, VI, 36; 31) This singular supreme maxim, as a purely formal maxim, can be regarded as the form of all our more particular maxims, and hence as being an element of all those more specific maxims. This choice of our own character Kant tells us is a timeless noumenal choice, which as noumenal would be beyond the awareness of the chooser; but such a choice is a presupposition of any holding of a person responsible for her own moral character. The end of action is described in the Tugendlehre as the matter of maxims (MdS, VI, 394-5), and this doctrine is anticipated by the discussion of the form and matter of maxims in the second Critique. (KdpV, V, 26-27). Of course, though there would be and could be only one formal maxim, which would be the form of all other maxims, there can be, and should be expected to be a plurality of ends, just because they are the material aspect of maxims.

The claim of Chapter One of the Grundlegung that the moral goodness of actions is a function of the "moral content" (sittliche Gehalt, G, IV, 398) of the maxim of the action is a consequence of the main doctrine, and does not itself entail a separate kind of maxim, as Atwell urged (see Part II, above). That is, for Kant moral goodness must originally be a quality of persons, and is a quality of the actions of persons only derivatively and consequentially. If a person's moral goodness is original and basic, it could not be acquired or accumulated by adding together the moral goodness of individual actions and subtracting the moral evil of other individual actions. We would be interested in the moral goodness of actions only because those actions exhibited or failed to exhibit the underlying moral quality of the agent. So the Grundlegung view that the maxims of some actions have "moral content" just means that such action maxims exhibit (or not) the moral goodness of the agent. (When St. Francis takes a drink of 
water because he is thirsty, he does not thereby reveal his inner moral quality of character.) I conclude that the moral goodness of persons is a quality defined by the purely formal maxim of the Religion, and revealed or not by certain action maxims according to Chapter One of the Grundlegung.

Why should we think that maxims also include ends? There are several reasons. First of all, Kant says that they do (MdS, VI, 395). Secondly, Kant's doctrine is that all human action is for the sake of an end (eg., see R, VI, 4; 4). Now the end of an action is what determines us to perform the action itself, for if it did not so determine us it would not be the end of the action. From this it follows that if the action is a part of the maxim, so must the end be. Otherwise the freely chosen action (which, in virtue of its freely chosen character, is regarded as within, a part of the maxim) would have been determined by something not itself freely chosen (because it is outside of the maxim), viz., the end, which would be a contradiction. ${ }^{14}$ In a sense, the more basic choices that we make on the material side of our maxims (i.e., more basic than our choices of actions) are of our ends or goals, since it is the choice of ends that determines our choice of actions. Also, Kant's doctrine of ends that are at the same time duties (the basis of his entire discussion of the Tugendlehre) would not be a part of his ethical theory unless ends were morally significant elements of our choices.

The three elements that have been mentioned must be distinct from each other. The choice of character is a choice of a formal maxim; the choices of ends and actions are choices on the material side of maxims. ${ }^{15}$ Therefore the former are distinct from the latter. And ends and actions are clearly distinct from each other and are distinguished from each other by Kant.

If this discussion is correct, maxims contain three distinct elements: a choice of one's character, a choice of basic ends of action, and a choice of kinds or policies of action.

We now turn to considering how these distinct elements are related to each other. How do these internal elements relate to one another for each of the distinguishable sorts of action-motivation complexes

(1) First consider a duty of virtue, performed from purely moral motives. In this case the full structure as described above is clearly present. This is the Kantian paradigm on which the above description 


\section{NELSON POTTER}

of the internally complex structure of the maxim is based. Here the moral goodness of the agent determines the dutiful end, which determines the action. For example, the Good Samaritan out of his moral goodness makes it his end to seek the happiness of others; because he has this end, he stops and renders assistance when he comes across the victim of robbery along the road.

(2) Now consider the performance of a perfect duty to others, such as not making a lying promise, or keeping a promise, or telling the truth in the face of temptation to lie, or returning a borrowed item as promised, where these actions are done from purely moral motives. Here again the moral goodness of the agent determines her action. We must say that the action is determined via an end, since Kant repeatedly insists that all human action is for the sake of an end. But what would the end be? This is not an easy question to answer, and there is, to say the least, some room for disagreement about the answer. Here I will sketch my answer to this question, though I have given a fuller answer elsewhere. ${ }^{16}$ The answer comes in two stages.

First, it might be thought that neither of the ends that are at the same time duties, nor any other end, is involved in such actions, since the Kantian doctrine of "ends that are at the same time duties" is developed only in reference to the duties of virtue, and we are here talking about a perfect duty to others. Yet Kant insists repeatedly that all action is for the sake of an end, and indeed that all maxims contain an end, and since the duties we are now discussing have been performed from the motive of duty, the end of such an action must itself be determined by the moral incentive, rather than by any mere personal desire. Since the two "ends that are at the same time duties" that Kant mentions, the perfection of oneself, and the happiness of others, are the only two morally determined ends that Kant ever mentions, it seems likely that one of these is involved even in the fulfillment of these duties that are not, or seem not to be, duties of virtue. I suggest that the distinction between duties of virtue and perfect duties to others is less significant than it might have seemed, especially when we are working within ethics, ie., when we are concerned that the inner motivations that cause us to perform morally required actions be purely moral motives. (For the sphere of ethics as concern with inner moral motivation, see MdS, VI, 219-220.) 
Kant himself discusses the duty not to lie as a violation of a duty to oneself in the Tugendlehre, though usually lying would be considered a violation of a duty to others. (See MdS, VI, 428-431) When we consider a duty to repay a loan, leaving aside consideration of any prudential issues about penalties in law or public opinion for the failure to repay, we will sometimes find that such a payment is to a large institution or a wealthy individual, who is not directly or significantly benefitted by any such payment. The only ever present goal in such repaying actions is the goal of not committing a moral violation, not doing something to violate one's own moral perfection. This reflects our feelings about such actions, I think; we do such actions because they are required, because they involve the keeping of a commitment, and out of a sense of moral self-respect. One's own moral character is always involved in such actions, apart from prudential concerns, and even when the wish to benefit others through one's action is not relevant.

Second, one thing which might obscure the relevancy of the dutiful end of one's own moral perfection is that the kind of actions we are talking about here are in every case abstentions, ie., negative actions. This is true even when such duties entail positive action such as repaying a debt or returning a borrowed item, for what is at stake in such cases is the avoidance of wrongful non-payments or nonreturnings. It is reasonable to ask how any abstaining is an action that can have a goal. Kant addresses this question as follows:

Negative duties forbid man to act contrary to the end of his nature and so have to do merely with his moral self-preservation; positive duties, which command him to make a certain object of choice his end, concern his perfecting of himself. Both of them belong to virtue, either as duties of omission (sustine et abstine) or as duties of commission (viribus concessis utere), but both belong to it as duties of virtue.

Thus one's moral perfection is not a direct goal of action for negative duties. The direct goal is a sort of second-level goal of not acting contrary to the primary and presupposed goal of one's own moral perfection. Such second level ends, though they are not direct aimings at the end of one's own moral perfection, are ends that presuppose and thus entail this goal as one's first level goal in such morally motivated action. The two levels of goals are simply a 


\section{NELSON POTTER}

consequence of the fact that we are talking about negative duties in such instances. Thus I preserve my moral character intact by paying my debt as required. Such duties, when they are considered as ethical duties, as duties where not just the action, but also the proper inner motivation is required, are thus far forth duties to oneself. Their alternative character as duties to others emerges when one considers them simply as action- requirements, abstaining from which violate the rights of another. Thus, depending on whether we are interested in the external action or the inner motive to action, they are duties to another, and duties to oneself.

How is it determined that it is wrong? I suggest that we answer this question as follows: The agent acts as he does because he understands that the categorical imperative as applied makes it clear that such an action could not be willed as a universal law, or would fail to respect the person being spoken to, or would violate positive law, which we have an obligation to obey. So finally the structure of action here is the same as in (1): The moral goodness of the agent determines the end which is at the same time a duty, which in turn determines the action. The main surprises and changes are (a) that something that we think of as a duty to others involves moral motivation having reference to the dutiful end of moral perfection, which is associated with duties to oneself, and (b) that our goal may be a second level end of preserving the first level dutiful end, because of the fact that many such actions are abstainings rather than positive acts.

(3) Next consider a morally permissible action motivated by happiness, as performed by a morally good person. Here there must be, it seems, two distinct candidate maxims relevant to the action: one is a personal maxim that calls for a morally unobjectionable action, such as, "When you're thirsty, seek out a drink of water." The second maxim would be the formal motivational structure of the morally good person that is lurking in the background of the action-specific first maxim, and that entails the rejection of any morally wrong maxim. The morally good person views the first maxim and judges it morally harmless, though in itself this first maxim neither has nor reveals any positive moral quality. Thus the non-moral desire that is embodied in the first maxim is taken up by the agent and made an end of action, but not an unconditional end, since the actions taken as means to fulfill the 


\section{MAXIMS IN KANT'S MORAL PHILOSOPHY}

end must morally permissible, and themotivational structure of the morally good person stands ready to intervene and prevent when necessary. So the specific happiness-maxims are adopted only upon condition of moral acceptability.

Let's also consider the formal/material language of Kant in connection with maxims. The happiness maxim is a material maxim, adopted because of its end. The morally good agent considers such maxims with respect to their form, and rejects some of them. Kant's way of speaking of such cases in the Religion does not envisage two distinct maxims, but rather speaks of our capacity for choice (Willkuer) taking up certain incentives into itself or into its language; this is the way of speaking characteristic of Kant's "Incorporation Thesis." But the main point is that for the morally good person the taking up of such incentives is conditional upon the proposed actions being morally acceptable.

This also gives us our model for (3a): Duties of virtue carried out based on morally pure motives, but involving some breadth (MdS, VI, 390), and hence some element of personal discretion. (Kant tells us that ethical duties are of broad obligation, which means some discretion is allowed in determining the specific action to be performed.) The morally good motive carries the agent's action all the way to limiting the range of actions. Eg., giving money as opposed to spending it on oneself in the simplest case comes down to choosing between a certain number of equally acceptable charities. The difference, if it makes a difference, is that the action-possibilities have been narrowed down to a certain number by the considerations of moral goodness which leave the agent personal discretion and preference only between or among those actions that have a certain very limited description ("giving \$x to an acceptable charity"). Thus such an action is characterizable as morally good, because one of the class of morally equivalent actions will be performed, based on purely moral motives; personal preference only determines which one. In contrast, in the absence of thirst, or some other personal belief in the benefits of a drink, no drink would be taken. These discretionary alternatives, just because they are understood to be discretionary, are morally equivalent, and the motives leading up to them are supposed to be identical, leaving aside considerations of personal preference. ${ }^{17}$ 
Notice the structure of such actions (types (3) and (3a)). There is a governing background maxim, a purely formal maxim of giving priority to moral considerations. There is a distinct and rather selfcontained personal candidate maxim, one governed by personal ends. In case (3), the resultant action, as one motivated by personal desires, does not exhibit any inner moral worth. Nevertheless the overall structure of maxims relevant to the action is that of a morally good person, because we can say that the personal maxim would be adopted and acted upon only if it were not in conflict with moral demands. We can call such a motivational structure "two-tiered."

In case (3a) the final action does exhibit moral goodness because, although it involves some personal discretion and preference, it is a member of a class of actions none of which would have been performed but for the moral motivation, we are supposing.

(4) Next consider morally impermissible actions motivated by happiness. In this case there is a conflict between the candidate-maxim of personal happiness, and the overseeing principle of moral goodness, and moral goodness loses (through our choice, Kant would emphasize). This contrasts with case (2), where there was also such a conflict, and morality prevailed. The entire structure of maxims is different from case (2), though that may not be apparent from observing the resultant action. The morally good person and the morally evil person may in similar circumstances seek a drink of water in exactly the same way for exactly the same reasons. Differences will become apparent only when the action is contrary to morality; in such a case the morally good person would defeat the candidate personal maxim, and perform the contradictory action, which would be one of types (1) or (2), but the evil person, giving preference to personal desire, would override the moral compunction, and adopt the personal maxim.

This account of action types (3) and (4) also helps makes sense of a certain aspect of Kant's theory of freedom. When the agent takes the morally innocent drink of water because she is thirsty, if she is morally good, she has given herself permission to do such a thing, or, to use the Kantian language of the Religion, she has taken up this nonmoral incentive into her maxim. Thus it becomes clear that the scope of freedom for Kant is not just action from duty. It is also, at least, action in accord with duty, which is not also action from duty. What 
about cases where the agent is not morally good, and gives herself permission to perform an action that is contrary to duty? Since the agent had it in her power to act differently, such an action is in accord with the basic formal maxim of the agent, which defines what moral evil is: I'll follow the moral incentive so long as it doesn't interfere with fulfillment of my own personal desires. (R, VI, 36; 31-2) So here the proper order of the incentives is precisely reversed. This policy choice is expressed (exemplified) in the present action. Since, Kant insists, both kinds of incentives are present and available, the moral agent was free to choose differently and such actions are also free, though the agent does not make use of the moral power she possesses to act differently. The two-tiered motivational structure that emerges when we consider such actions, where every desire/action combination that clamors for fulfillment is yielded to or not, depending on the decision of the agent's executive moral capacity for choice, helps make sense of Kant's claim that the agent is free also in actions not from the motive of duty, even though freedom is defined in terms of the power of acting from the motive of duty (MdS, VI, 226), or if you will, in terms of the causal power of such action. ${ }^{18}$

Is there a difference between the morally good and the morally evil person taking an innocent drink of water? Yes and No. Yes, there is a difference because their governing formal maxim is different for the two agents, and this difference as a formal aspect of any of the agent's maxims is present in such an innocent action, as much as it is in any other action. No, because the fact that the proposed action is morally innocent means that the difference between the underlying formal maxims of the two agents does not make a difference for this action. We could describe the inner difference in this way. The agent's selfinterested motivation is unconditionally subscribed to in the case of the evil, merely conditionally (ie., conditionally upon its moral acceptability) by the morally good agent.

(5) For the sake of a certain kind of completeness, let us consider another sort of case of conflict of candidate maxims, where two maxims are of the same sort, and one finally governs. The agent is hungry and considers eating an available candy bar, but she reflects that the candy bar will be fattening, and decides against eating it. Both the action and the omission are, or rather would be, based on personal 
ends, not moral ends. Similar kinds of issues are raised by a case of conflict of obligations; kindness would require withholding an unpleasant truth, and respect for self-determination of the hearer would require speaking it. (Kant tells us that there are no conflicts of obligation, only conflicts of grounds of obligation (MdS, VI,224), but I understand this to mean merely that there are no conflicts of totiresultant duties, only of prima facie duties) Both of these instances are cases of conflicting candidate maxims on the same level: moralmoral or nonmoral-nonmoral. They would both be resolved by the agent's determination that one governs or dominates the other, at least in the individual situation of choice. Kant has very little if anything to say about resolution of conflicts among same sort candidate-maxims. The one sort of case for which he explicitly envisages such a conflict, and discusses its resolution is the case of conflicts between moral and personal maxims. Governing such conflicts he tells us is a purely formal "supreme maxim," which determines how such conflicts will be resolved, and thereby also defines the deciding agent's moral character. The very phrase "supreme maxim" suggests that it is a second order maxim, on a different and higher level. But arguably we also need second order maxims to resolve same level conflicts, maxims Kant does not provide us with. I leave the issue at this point, w' _re Kant leaves it: we get from Kant only a suggestion of second order maxims for one kind of crucial case (conflicts between moral and personal candidate maxims).

(6) Now we consider a case where moral and personal happiness motives cooperate. This is a complicated sort of case that cannot be discussed fully here. I will here simply state without argument that there is in fact no such thing as Hensonian overdetermination of actions $^{19}$, at least when we are talking about actual rather than dispositional motives, and add that if and when there are cases of cooperating motives producing an action, there must be two maxims simultaneously at work, neither of which is quite the maxim of the action (because neither by itself fully determines the action); there must be two maxims because, although the actions mentioned in the two maxims would be the same, the ends would probably be distinct, and underlying motivational structure would be different also. Each 


\section{MAXIMS IN KANT'S MORAL PHILOSOPHY}

maxim would be at most a partial cause in such a case; otherwise the cause would be greater than the effect, which is not possible.

As a consequence of the above discussion we can see that there is an interesting difference between moral and personal maxims. The former have their origin in a supreme maxim defining one's basic moral personality and the latter do not. In fact to be morally evil is to be willing to abandon this underlying unity and integrity of personality in the fulfillment of merely personal ends, and we get here one of the reasons in Kant's view for preferring moral over personal maxims, and one of the reasons why the former are said to be based in autonomy, the latter in heteronomy.

The structure of maxims that shows itself through these different sorts of actions has moral goodness as the initial motivational source determining actions in the morally good person. With respect to the moral person there is a sort of "transcendental unity of motivation," as we could call it. In contrast personal ends are simply a plurality of discrete desires, that we typically take care of in turn, in distinct fashion: we are in turn hungry, angry, too cold, sleepy, envious, feeling strong sexual desire, and wishing to be entertained. Each of these is distinct and independent of the others, and is fulfilled in a distinct way; hence desires tend to have as many sources as there are desires, and we have no general second-order desire to have or fulfill desires. In contrast the single source unity of morality, so far as it operates, operates through the distinct parts of our maxims, from the most basic moral goodness of the person, which determines the agent's adoption of the ends that are at the same time duties, to the specific action moral maxims which are determined by the agent's basic moral goodness, and which determine in turn all those actions that show forth that same quality of moral goodness. Admittedly, the detail of the specific actions that the inner quality of moral goodness can lead us to is as great as that for desire based maxims, but in the case of desire based maxims, their origin may be traced back only so far as the specific desire that is their basis.

Let me conclude this section with a problem raised by Allison, in his attempt to characterize the relation of the purely formal "supreme maxim," which he calls, following Kant, the agent's Gesinnung: 
Since the relationship between a maxim as a "general determination of the will" and the more specific practical rules and particular actions falling under it is logical rather than causal, the relationship between the fundamental choice of Gesinnung and the particular choices that rational agents make in light of their Gesinnung is likewise broadly logical rather than causal.

Accordingly, the particular actions of a rational agent are not to be regarded, in Leibnizian or Humean fashion, as the causal consequences of that agent's Gesinnung.

(KToF, p. 142)

This raises the question what the relation of the elements of a maxim is as we have described them. I have followed Kant's practice of talking about these relations in terms of "determination." That word has a causal flavor to it, but recall that the causal relations mentioned here are free causes, and hence not empirical efficient causes in accord with the principle of the Second Analogy. Such causes may be more like rationalist causes that entail their effects, or like Aristotelian formal causes, rather than Humean efficient causes where the cause and the effect are clearly distinct, and known to be related only through experience. The relation between end and action (an aspect of the structure of maxims that Allison does not consider in detail) does seem quasi-causal rather than "logical" since mention of the agent's end would be essential in explaining why she performed the action. As we saw, Kant says in the second Critique

If a rational being can think of its maxims as practical universal laws, he can do so only by considering them as principles which contain the determining grounds (Bestimmungsgrund) of the will because of their form and not because of their matter. (KdpV, V, 27)

This passage does not directly address the issue of internal relations of parts of maxims, but rather the relation of an entire maxim-structure to the "will", by which it determines the will to action. Yet given what Kant says here it seems hard to avoid the idea that in the morally good 


\section{MAXIMS IN KANT'S MORAL PHILOSOPHY}

agent, the commitment to morality determines the goal of the agent's action (i.e, the form determines the material of the maxim), and the action itself, as opposed to the end and action's being determined by a personal desire. Hence the relations of parts are causal rather than "logical."I have often used causal language in these connections, because I want to emphasize the connections between justification and motivation, and hence between reasons and causes, in Kant's moral philosophy. However, this issue is a difficult and complicated one that calls for more detailed consideration than it can be given here.

\section{$\mathrm{V}$}

The conception of maxims just offered has some immediate advantages in relation to earlier accounts. The notion that maxims contain not only references to actions but to ends of action is indispensable for an adequate understanding of the doctrine of ends that are at the same time duties that is so central to the Tugendlehre. ${ }^{20}$ And the fact that maxims have both a formal and a material aspect, with incentives or motives relating to the formal side, and actions and ends of action relating to the material side, is quite central to understanding the unity of Kant's moral philosophy, and, in particular, the close connections between his theories of right and wrong and of moral goodness.

Let me sketch a certain kind of ideal interpretation of Kant on maxims that may not ever have been the view of any actual interpreter. It is, I think, a view and an approach that has colored and influenced many actual interpretations. It would go as follows: Think of rule utilitarianism, for example, as discussed by David Lyons, as mentioned above. According to most conceptions of rule utilitarianism, one key task is to come up with descriptions of actions for one's secondary rules (those more specific rules that would fall under the maximally broad and abstract utilitarian principle itself) that would mark off kinds of actions that will have the best consequences, and perhaps that would also meet certain other desiderata, such as being readily identifiable by agents, and in other respects not being too difficult to follow. These rules have the sole function of marking off classes of actions, and have no mentioned motivational or psychological basis in the agent, any more than "Three strikes and you're out" does. We might say that such 


\section{NELSON POTTER}

rules have no psychological or motivational depth. They are simply rules that may be arrived at by following a certain procedure (algorithm) and that are then recommended to be followed. The procedure is one of applying a broader, more abstract teleological moral rule to a certain set of factual circumstances to derive these more specific rules. It would be easy to picture Kant in terms of this model. He appears to have a structurally similar view, except that his basic maximally abstract moral rule--the one he calls the categorical imperative--is deontological and "formal" in character rather than teleological. He tells us that the agent-rules to which the categorical imperative is to be applied are what he calls "maxims." So maxims could then be conceived of as secondary rules after the model of rule utilitarianism, and the task of formulating morally correct maxims would be seen as a problem of marking off classes of actions, not as ones that have certain consequences, as for the utilitarian, but as ones that have certain formal inherent moral characteristics, as appropriate to a deontological formalist theory. If this were an accurate model on which to understand Kant's moral philosophy, Alastair MacIntyre would have been been correct when he wrote that "In Kant's moral writings we have reached a point at which the notion that morality is anything other than obedience to rules has almost, if not quite disappeared from sight." 21 And when we realize in addition that according to this line of thought there is nothing extra-formal to justify the derived moral rules, as there is for the utilitarian, we begin to see why Kant's moral philosophy is sometimes described as a sterile formalism.

I do not here undertake to criticize this entire interpretive approach. But I do think that the conception of maxims that it embodies is one that has been shown to be incorrect by the present discussion. I have argued that maxims are not principles or rules in the sense proposed. Rather they are psychological free causal entities that have considerable psychological depth and internal complexity, and as such they are "subjective principles" that are central to human choice and action, "principles" in the sense of causal principles that produce actions. Kantian maxims are precisely products of our inner, deepest moral character, and, as described by Kant, themselves refer to basic aspects of character and virtue. In fact, Kant's ethics is a sort of virtue ethics, 
which mainly differs from what today are usually called "virtue ethics" in that for Kant there is only one virtue: moral goodness. (But see MdS, VI, 406, where Kant speaks of "a plurality of virtues.") The more common interpretation of Kant's ethics that centers around the application of the categorical imperative and the four examples of the Grundlegung responds to a real part of his total moral theory, but one which is a consequence of more fundamental elements in his view.

This close connection between action and motive that is embodied in the concept of "maxim," can also be seen clearly in a number of other central conceptions of Kant's moral philosophy. Consider, for example, the "third proposition" from Chapter One of the Grundlegung, namely that "Duty is the necessity to act out of respect (Achtung) for the law." (G, IV, 400) This statement is hard to understand unless we realize the double character of the subject term, "Duty." If we think of duty as simply "morally required action," it is difficult to see why Kant would describe it in terms of the unique moral emotion, Achtung, which has to do not with outer action but with inner motivation.22 Duty does have the aspect and meaning of "morally required action," but in this statement it also has the aspect and meaning of inner motivational commitment to such action. This two-sided characteristic of basic moral conceptions in Kant also pertains to "maxim" and to the term used to define it, "principle," as we have seen, and, arguably, to "categorical imperative" itself, and to its description as "the supreme principle of morality." The term "principle" has a double meaning, as a statement formulated in words, but also as a psychological entity having a causal force, which, as causal, has to do with motivation and with the inner aspect of morality.

What we see when we consider the formal and the material aspects of maxims, is the way in which justification of actions as right or wrong mirrors motivation leading to those same actions in the morally good person. It is because of this sort of mirror-like relationship that Kant in the Grundlegung (as Barbara Herman emphasizes ${ }^{23}$ ) criticizes the nonmoral emotions as a motivation for doing one's duty by saying that the connection between the motive and the duty is merely accidental (G, IV, 390. cf. 398). According to the views Kant is criticizing, justification to do $\mathrm{A}$ is one thing, motivation to do that same thing is something entirely distinct, with the relation of the two 


\section{NELSON POTTER}

contingent. In contrast, on Kant's view, the motive of duty is such that there is an identity of justifying and motivating reasons. Hence for the agent who acts from the motive of duty the connection between justification and motivation is essential and necessary, not accidental. Justification yields conclusions about obligatory, permissible, and wrong actions; motivation yields those same actions being performed from the morally good motives of duty. Hence moral goodness is mirrored by moral right and wrong, just as in the morally good person right action flows from the motive of duty.

Now that we have seen how closely connected motivation and justification are in Kant, we can say the following: Moral goodness is basic, moral right and wrong derivative. To perform a morally right or obligatory action is to perform the action that the morally good person would perform. Justification replicates motivation in the morally good person. And unless the purely moral motivation that is present in the morally good person were possible, there would be neither freedom nor morality--and hence also no moral justification.

I have just stated what I take to be the general viewpoint concerning Kant's moral philosophy that arises from our detailed consideration of the nature of maxims. Let us conclude this essay by considering what implications the present interpretation has for the issue of criteria for formulating correct actions descriptions in maxims. This question of proper formulation was a part of the traditional topic of the "application of the categorical imperative." I wish to refer to an earlier article of mine to facilitate my clarifying what the correct account of this issue is in the light of the earlier comments about maxims as "principles."

In my earlier article "How to Apply the Categorical Imperative,"24 I discussed maxims, and proposed that it was important to understand that maxims include ends. I was concemed there with how to formulate the single correct statement of the maxim for the purposes of moral evaluation, specifically in the lying promise example from the Grundlegung. I proposed that the action mentioned in the maxim should be described as a means to the end of the action, the end also being mentioned as a part of the maxim. Hence all and only causally relevant characteristics of the proposed action would be mentioned in describing the action. This was an adaptation of David Lyons' proposal 
for how action descriptions occurring in rule utilitarian moral rules should be described (in Forms and Limits of Utilitarianism ${ }^{25}$ ), an adaptation to a non-utilitarian moral theory which still understood human actions in teleological terms, ie., as means to ends. There were two elements of this essay that hint or point toward the interpretation of maxims as principles that I'm now presenting. One was my proposal for how the ends of action should be described: as reflecting the psychological reality of the adoption and acceptance of ends. The other was the suggestion that maxims should be understood as affected in their formulation by a Kantian conception of the spirit of the law, that is, that, intuitively speaking, a maxim should be verbally formulated in such a way as accurately to reflect the underlying psychological reality of the maxim as a subjective principle. But there was not an explicit understanding that maxims are after all principles, where that means causal entities.

So now, the basic test for correctness of action descriptions occurring within maxims is whether they accurately reflect the underlying psychological-motivational principle. Hence it is one of something like descriptive accuracy. Only it is something like intentions that are being described, rather than physical objects, but intentions understood as principles that are causally effective in action. When I wrote that article I did not fully understand the motivational role of maxims--neither the double meaning of "principle" in the definition of maxims, nor the implications of the fact that the moral goodness of an action is a function of the moral content of its maxim, nor that the supreme maxim defines human moral goodness. Nevertheless, with appropriate revisions these earlier views can still be defended.

My final response to the problem of criteria for action-descriptions as they occur in maxims is that the issues are quite different than they are for the rule-utilitarian, as described above. When stating a maxim the aim is accurately to formulate the actual aims and goals and underlying motives of the agent. These are the factors that control the correct formulation of maxims, not picking out terms that refer to and hence mark off proper ranges of actions, with respect to some external standard of consequences. This conception eliminates the need to think in terms of multiple possible alternative formulations for one and the 


\section{NELSON POTTER}

same maxim and agent. This is not to say that it is easy to arrive in every case at a correct statement of the maxim; it is to say that the traditional problem of criteria for determining action- descriptions is a real issue for the rule utilitarian in a way that it was not for Kant. Among other things the present interpretation of maxims has the advantage of explaining what would otherwise seem to be Kant's puzzling silence on the problem of relevant action descriptions in maxims.

According to the interpretation defended here, the answers to the two unresolved issues in Allison's interpretation of maxims (see the end of Section III above) are: (1) A unique statement of a given maxim should in principle be possible, because such a statement is not an arbitrarily formulated rule but a description of an independent psychological entity. The different formulations of maxims may relate to the fact that it is convenient to consider a maxim in relation to different actions it produces. The fact that there may be different formulations of a maxim offered introduces fewer problems when it is realized that such formulations have a underlying psychological principle to be tested against for accuracy. (2) The "standard account" of maxims is going to be incorrect insofar as it is offered as a complete interpretation, because it fails to take account of Kant's view that we not only choose and hence are responsible for our own actions, but that we also choose our ends of action and our own underlying character.

In this section I have discussed in some detail the model of rule utilitarianism as a model for interpreting Kant's philosophy, and have argued that it is shown to be an inadequate and misguided model by the interpretation of maxims that I've offered. This is only one of the implications of this interpretation of maxims for understanding Kant. I list here some other future directions for exploration of implications of the present interpretation of maxims, some of which have been mentioned in passing above: (1) That the Kantian doctrines of moral goodness and right and wrong are bound up with one another very tightly, with motivating reasons and justifying reasons for action mirroring one another in the case of a morally good person. (2) That the concept of moral goodness or good will is what is basic in Kant, with matters of right and wrong derivative, making the Kantian moral philosophy into a version of what is today called "virtue ethics." (3) 


\section{MAXIMS IN KANTSS MORAL PHILOSOPHY}

That basic terms in Kant's moral philosophy such as "duty" and "principle," and "imperative," as well as "maxim," have a two-sided character, referring to the causal-motivational side of action, as well as to their verbal formulation in rule-like statements. (4) That the different aspects of Kant's moral philosophy - his theories of freedom, of moral goodness and virtue, of right and wrong - have more coherency than might have been thought on other interpretations. (5) That this interpretation will enable us to take some major steps towards understanding the derivation of the duties of virtue in the Tugendlehre, including the difficult and controversial duties to oneself.

The concept of maxim is so central to Kant's moral philosophy that any interpretation of it has implications no matter which way we turn. Here I have been able to discuss in some detail those implications only in one such direction. ${ }^{26}$

\section{UNIVERSITY OF NEBRASKA-LINCOLN LINCOLN, NEBRASKA 68588-0321}

USA

\section{NOTES}

1 New York, Alfred A. Knopf, 1961. Chapters VIII and IX.

2 Kant's Theory of Freedom, Cambridge, Cambridge University Press, 1990. See p. 40. This term comes from Kant, R, VI, 24; 19. Future references to Allison's book will be given in the text following the abbreviation KToF. References to Kant's works will also be given in the text; references are to the volume and page of the passages referred to in the Prussian Academy edition of Kant's works (Kants gesammelte Schriften, herausgegeben von der Deutschen (formerly Koeniglichen Preussischen) Akademie der Wissenschafter, 29 volumes (Berlin: Walter de Gruyter (and predecessors), 1902). Most English translations of works referred to include these page numbers marginally. However, Religion Within the Limits of Reason Alone translated by Theodore $M$. Greene and Hoyt $H$. Hudson, as revised by John Silber (New York: Harper Torchbooks, 1960) does not; references to this work (abbreviated $\mathrm{R}$ ) will give first the Akademie volume and page, followed by the page of the English translation. Other 
NELSON POTTER

abbreviations: $\mathrm{G}=$ Grundlegung zur Metaphysik der Sitten. $\mathrm{KdpV}=$ Kritik der praktischen Vernunft. MdS=Metaphysik der Sitten.

3 As mentioned above this was Chapters VIII and IX.

4 Philosophical Quarterly, 7 (1957), 50-62. Reprinted in Robert Paul Wolff, editor, Kant: A Collection of Critical Essays. Garden City, New York: Anchor Books, 1967.

5 This was in his essay "Utilitarianism, Universalization, and our Duty to Be Just," Proceedings of the Aristotelian Society. Vol. 52, (195253).

6 Onora Nell (now O'Neill), Acting on Principle. New York, Columbia University Press, 1975.

7 London, Oxford University Press, 1965. For the reference to my article, see note 22 below.

8 Dordrecht, Martinus Nijhoff Publishers, 1986. Let me note here that there is another classic interpretation of maxims that is similar to Atwell's in distinguishing different kinds of maxims. H. J. Paton, The Categorical Imperative: A Study in Kant's Moral Philosophy, 3rd. edition, (London: Hutchinson \& Co., 1958), pp. 136-8, distinguishes what he calls formal and material maxims. For a critique of this view of maxims see the author's "Paton on the Application of the Categorical Imperative, " Kant-Studien, 64. Jahrgang, Heft 3, 1973, pp. 411-422.

9 Ibid., p. 34.

10 I will discuss this a bit more below; for a fuller account of this point see my essay in preparation, "Kant and the Moral Worth of Actions."

11 The works being discussed are Otfried Hoeffe, "Kants kategorischer Imperative als Kriterium des Sittlichen" in Ethik und Politik, edited by Hoeffe (Frankfurt: Suhrkamp, 1979). Rudiger Bittner, "Maximem," Akten des 4. Internationalen Kant-Kongresses, 6-10 April 1974. (Berlin: de Gruyter, 1974), pp.485-98. Onora O'Neill, "Kant After Virtue," and "Universal Laws and Ends in Themselves," both now reprinted in her book Constructions of Reason: Explorations of Kant's Practical Philosophy. (Cambridge, Cambridge University Press, 1989).

12 Constructions of Reason, p. x, 21-25, 128 and passim.

13 Allison mentions in footnote 30 to p. 93 that three other authors, like himself, propose hierarchies of maxims, based on different levels of generality of action description. Lewis White Beck, A Commentary on Kant's "Critique of Practical Reason" (Chicago, University of Chicago Press, 1960), p. 118. H. J. Paton, The Categorical Imperative: A Study in Kant's Moral Philosophy, 3rd. edition, (London: Hutchinson \& Co., 1958), pp. 136-7. Christine Korsgaard, "Kant's Analysis of 
Obligation: the Argument of Foundations I," Monist 73 (1989), pp. 311-40, p. 324. Korsgaard's hierarchy of maxims does not consist, however, of more and less broad and abstract descriptions of a proposed action, each therefore grouping a different set of other actions with itself, but rather consists of a range of means and ends, with each relative end a means to a further end; this is a view I have no disagreement with.

14 Throughout this discussion I follow Kant in using the word "determine" in contexts that relate to human motives and actions to mean a causal relation, but a free causal relation, ie., a sort of determination of an action which is a result of an agent's free choice, as, for example, when the agent's adoption of an end determines her commitment to perform a specific action. For more on this see below.

15 Onora O'Neill in her Acting on Principle identifies ends (Zwecke) and motives (Triebfedern) with one another, an obvious mistake in interpreting Kant in the light of what is said here, and one that would make it difficult for her account of maxims there to be correct in other respects. This identification, on the other hand, is natural and common in English speech; for example when the detective investigating a murder is looking for someone who had a "motive", she is typically looking for someone for whom the murder would be a means to an end.

16 A more detailed exposition of my views on this issue is in "Reply to Allison," forthcoming in Jarhbuch fuer Recht und Ethik, as a reply to "Kant's Doctrine of Obligatory Ends," by Henry Allison, which will appear in the same issue.

17 The interpretation of the doctrine of breadth is itself a difficult matter. I have proceeded in this discussion as if the doctrine permitted significant merely personal discretion in meeting such obligations. Not all interpreters accept this. However, for any such interpreter, actions I've listed as (3a)-type actions become type (1) actions.

18 Allison discusses this point in KToF, 133-136. Also see my own essay, "Does Kant have Two Concepts of Freedom?" in Akten des 4. Internationalen Kant-Kongresses, G. Funke and J. Kopper, eds. Berlin: de Gruyter, 1974 , p. $590-6$. Also notice that Kant is not willing to propose that humans come any closer to evil than they do when they allow personal preference to override moral requirement. They do not reach the point of doing evil for the sake of evil, as Milton's Satan in Paradise Lost, who said, "Evil, be thou my good." He has been criticized for this by John Silber in his long introduction to the Greene and Hoyt translation of Kant's Religion (see note 2 above). See pp.cxxixff. 
Obligation: the Argument of Foundations I," Monist 73 (1989), pp. $311-40$, p. 324. Korsgaard's hierarchy of maxims does not consist, however, of more and less broad and abstract descriptions of a proposed action, each therefore grouping a different set of other actions with itself, but rather consists of a range of means and ends, with each relative end a means to a further end; this is a view I have no disagreement with.

14 Throughout this discussion I follow Kant in using the word "determine" in contexts that relate to human motives and actions to mean a causal relation, but a free causal relation, ie., a sort of determination of an action which is a result of an agent's free choice, as, for example, when the agent's adoption of an end determines her commitment to perform a specific action. For more on this see below.

15 Onora O'Neill in her Acting on Principle identifies ends (Zwecke) and motives (Triebfedern) with one another, an obvious mistake in interpreting Kant in the light of what is said bere, and one that would make it difficult for her account of maxims there to be correct in other respects. This identification, on the other hand, is natural and common in English speech; for example when the detective investigating a murder is looking for someone who had a "motive", she is typically looking for someone for whom the murder would be a means to an end.

16 A more detailed exposition of my views on this issue is in "Reply to Allison," forthcoming in Jarhbuch fuer Recht und Ethik, as a reply to "Kant's Doctrine of Obligatory Ends," by Henry Allison, which will appear in the same issue.

17 The interpretation of the doctrine of breadth is itself a difficult matter. I have proceeded in this discussion as if the doctrine permitted significant merely personal discretion in meeting such obligations. Not all interpreters accept this. However, for any such interpreter, actions I've listed as (3a)-type actions become type (1) actions.

18 Allison discusses this point in KToF, 133-136. Also see my own essay, "Does Kant have Two Concepts of Freedom?" in Akten des 4. Internationalen Kant-Kongresses, G. Funke and J. Kopper, eds. Berlin: de Gruyter, 1974, p. 590-6. Also notice that Kant is not willing to propose that humans come any closer to evil than they do when they allow personal preference to override moral requirement. They do not reach the point of doing evil for the sake of evil, as Milton's Satan in Paradise Lost, who said, "Evil, be thou my good." He has been criticized for this by John Silber in his long introduction to the Greene and Hoyt translation of Kant's Religion (see note 2 above). See pp.cxxixff. 


\section{NELSON POTTER}

19 Richard G. Henson talks about the possibility of overdetermination of actions as a possibility Kant failed to consider in his "What Kant Might Have Said: Moral Worth and the Overdetermination of Dutiful Action," Philosophical Review 88 (1979), pp. 39-54. I owe my belief and argument (being developed in works in preparation) on this point and on many other points in this paper to the insights of Marcia Baron in the unpublished manuscript of her book in preparation.

20 For details on this see my article "Kant on Ends That Are at the Same Time Duties," Pacific Philosophical Quarterly 66 (1985) 78-92.

21 After Virtue, Notre Dame, University of Notre Dame Press, 1981. p. 219. Cf. pp. 42, 112.

22 The Kantian doctrine of the moral emotion of respect (Achtung) is a complicated theory in itself that Kant works out most fully in Chapter Three of the Critique of Practical Reason. Without going into any of those details, the moral emotion is an effect of the presence of moral motives, and hence reflects the inner, central elements of the agent's moral personality.

23 In her "On the Value of Acting from the Motives of Duty," Philosophical Review 90 (1981), pp. 359-82.

24 Philosophia Volume 5, No. 4, pp. 395-416, October 1975.

25 Op cit.

26 I wish to acknowledge the help in the preparation of this paper that came from comments by readers of earlier drafts including Henry Allison, Marcia Baron, Philip Hugly, Jane Kneller, Joseph Mendola, and other colleagues in my department, as well as the usefulness of ideas gained from reading parts of an unpublished book manuscript on Kantian ethics by Marcia Baron. 


\section{NELSON POTTER}

19 Richard G. Henson talks about the possibility of overdetermination of actions as a possibility Kant failed to consider in his "What Kant Might Have Said: Moral Worth and the Overdetermination of Dutiful Action," Philosophical Review 88 (1979), pp. 39-54. I owe my belief and argument (being developed in works in preparation) on this point and on many other points in this paper to the insights of Marcia Baron in the unpublished manuscript of her book in preparation.

20 For details on this see my article "Kant on Ends That Are at the Same Time Duties," Pacific Philosophical Quarterly 66 (1985) 78-92.

21 After Virtue, Notre Dame, University of Notre Dame Press, 1981. p. 219. Cf. pp. 42, 112.

22 The Kantian doctrine of the moral emotion of respect (Achtung) is a complicated theory in itself that Kant works out most fully in Chapter Three of the Critique of Practical Reason. Without going into any of those details, the moral emotion is an effect of the presence of moral motives, and hence reflects the inner, central elements of the agent's moral personality.

23 In her "On the Value of Acting from the Motives of Duty," Philosophical Review 90 (1981), pp. 359-82.

24 Philosophia Volume 5, No. 4, pp. 395-416, October 1975.

25 Op cit.

26 I wish to acknowledge the help in the preparation of this paper that came from comments by readers of earlier drafts including Henry Allison, Marcia Baron, Philip Hugly, Jane Kneller, Joseph Mendola, and other colleagues in my department, as well as the usefulness of ideas gained from reading parts of an unpublished book manuscript on Kantian ethics by Marcia Baron. 